\title{
The Socio-Cultural Factors in the Common Strategic Planning in European Territories: Principles for Sustainable Development Extracted from Borderlands
}

\author{
RUI ALEXANDRE CASTANHO ${ }^{1}$, LUÍS LOURES ${ }^{2,3}$, JOSÉ CABEZAS $^{2,4,5,8}$, JACINTO \\ GARRIDO VELARDE ${ }^{6,7,8^{*}}$ \\ 1. Faculty of Applied Sciences, \\ WSB University, 41-300 Dąbrowa Górnicza, POLAND \\ 2. VALORIZA, Research Centre for Endogenous Resource Valorization, Polytechnic \\ Institute of Portalegre (IPP), 7300-110, Portalegre, Portugal \\ 3. Research Centre for Tourism, Sustainability and Well-being (CinTurs), University of \\ Algarve, 8005-139 Faro, Portugal \\ 4. Institute of Research on Territorial Governance and Inter-Organizational Cooperation, 41- \\ 300 Dabrowa Górnicza, Poland \\ 5. Environmental Resources Analysis Research Group (ARAM). University of Extremadura, \\ 06009 Badajoz, Spain \\ 6. CITUR-Madeira-Centre for Tourism Research, Development and Innovation, \\ 9000-082 Funchal-Madeira, Portugal; jgvelarde@unex.es \\ 7. Department of Social Sciences, Languages and Literatures, University of Extremadura, \\ 06071 Badajoz, Spain \\ 8. University Research Institute for Sustainable Territorial Development (INTERRA), \\ University of Extremadura, SPAIN
}

\begin{abstract}
The large number of borderlands existing in European territory contains many ventures of Cross-Border Cooperation $(\mathrm{CBC})$. Nonetheless, the management strategies related to such projects and the sustainable development they bring to the regions still raise many questions. Considering the little knowledge regarding the management and governance of borderland territories, the present research through the analysis of nine CBC projects (eighteen European border cities) aims to provide further insights from a common strategic planning perspective. The study was projected to locals, experts, and technicians related to the border cities' planning. In this regard, the participants were asked through questionnaires about their perceptions and feelings about the success of the border-cooperation projects in their area of residence or work. Thereby, the investigation enabled us to identify and isolate the five essential factors and challenges to consider from a socio-cultural perspective: (i) Sense of belonging and break cultural barriers; (ii) Diverse infrastructural offer - Euro Citizenship; (iii) Better life's quality standards; (iv) Retain young and talented people; and Public participation.
\end{abstract}

Key-Words: - Cross-Border Cooperation (CBC); Regional Planning; Strategic Planning; Societies; Sustainable Development; Territorial Governance and Management.

Received: August 27, 2020. Revised: October 6, 2020. Re- revised: October 29, 2020.

Accepted: November 9, 2020. Published: November 13, 2020. 


\section{Introduction}

The ventures of $\mathrm{CBC}$ encouraged the making of a comprehensive system of connections among individuals and states, which empowered the accomplishment of a few political, economic, natural, and sociocultural win-win-situations $[1,2,3$, 4]. Even if these relationships occur more often in Europe, $\mathrm{CBC}$ is a process carried out worldwide. We have the examples of a few CBC Projects between the United States of America and Mexico (North America), India-Pakistan (Asia), Turkey-Azerbaijan (Europe-Asia), Argentina-Chile or Brazil-Bolivia (South America), among numerous different models through the globe $[5,6,7,8]$.

Nevertheless, as much as we produce about CBC in the EU and carry efforts to expand cooperation in different sectors of society are highlighted, due to institutional and administrative difficulties, cooperation has been limited in the vast majority of countries. This cooperation is sometimes strictly economic $[9,10,11,12,13,14,15]$.

In recent decades, an increasing amount of $\mathrm{CBC}$ projects have been established in European territories. However, the management strategies related to such projects and the sustainable development they bring to the regions still raise many questions $[10,11,12,16,17,18,19]$.

Besides, in the thematic literature related to common strategic planning, there are no many references about a far-reaching way of how $\mathrm{CBC}$ and its implementation and management should be carried out on these borderlands territories $[19,20$, $21,22,23,24]$.
Thereby, and bearing in mind the little knowledge regarding the management and governance of borderland territories, from a joint strategic planning perspective, the present research aims to answer the following questions: Which are the factors and processes implicated in the long-term territorial sustainability of $C B C$ projects and strategies of Cityto-City Cooperation (C2C) from a Socio-Cultural perspective? Which are the guidelines and principles that the decision-makers and main-actors should follow for proper and successful implementation of those factors?

Therefore, nine European Cross-Border Cooperation (CBC) strategies and projects were chosen, and the public and technicians' perceptions assessed.

The current investigation enables us to improve the understanding of how the involved stakeholders and main-actors of border regions and cities should manage the critical factors for $\mathrm{CBC}$ and which principles they may implement to reach success in their cooperation initiatives, strategies, and projects. The study is based on exploring the perceptions of the citizens and main actors implicated in the selected case studies' border cooperation projects.

Thus, the study initiates with an opening section. It is succeeded by a methodological framework concerning the used proceedings on the experimental part of this research, the outcomes, the inherent discussion and conclusions, and the future research paths.

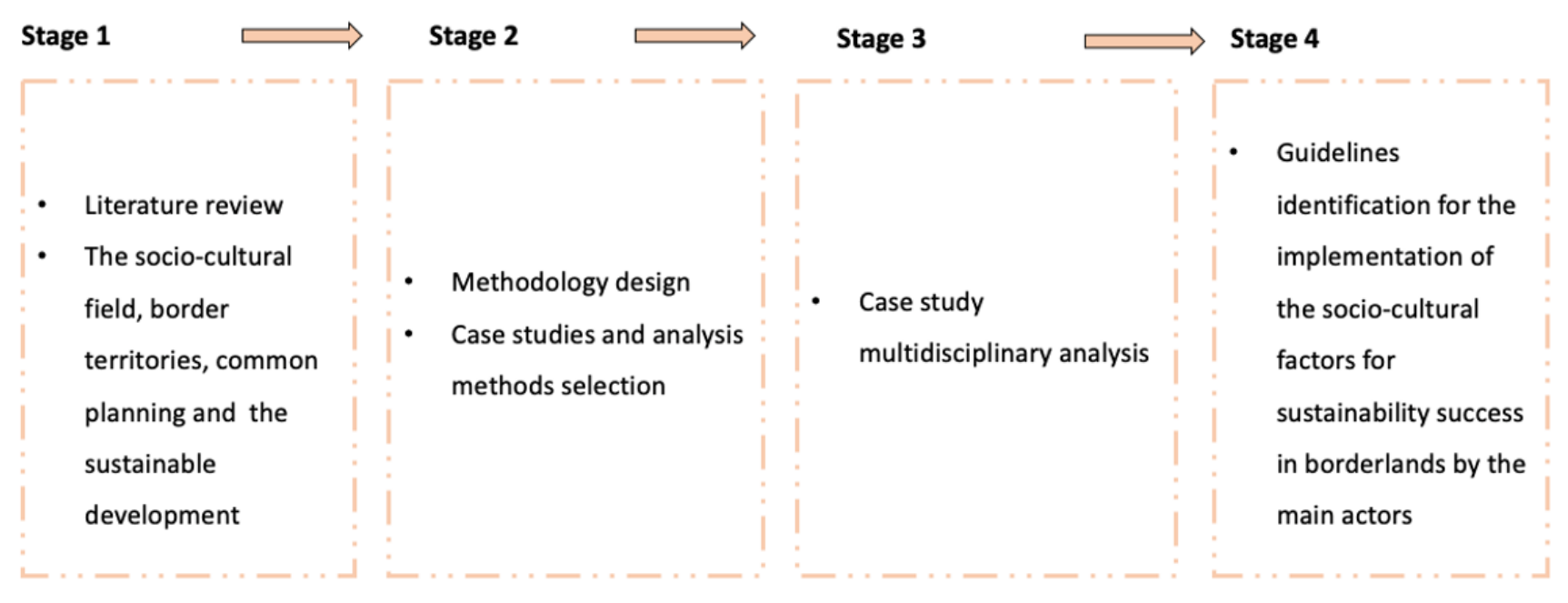

Figure 1: Methodology stages (Authors). 


\section{Problem Formulation}

The current research imposed various procedures and methods across the study, involving direct and indirect research procedures and instruments. The authors devoted a considerable quantity of time and focused on the design of a methodological section.

The methodological section was split into four major stages, closing with the guidelines for the implementation of the Socio-Cultural factors for Sustainability Success in Borderlands by the main actors (Figure 1). The stages are as follows: literature review, case study selection criteria, analysis of the case studies through a Case Study Research Method (CSR) [25], and the guidelines definition.

Thereby, the author collected the data by former examinations carried out on the selected locations. The site examinations have analyzed the design, planning, and implementation processes of the respective case studies. In this regard, the study understand a vast scope of problems, taking into account not only the present knowledge regarding borderlands, common strategic planning, and the Socio-Cultural dynamics in those areas.

Having in mind the purpose of the investigation, nine case studies were chosen (Figure 2). For this purpose, criteria for the selection of the case studies was set as:

(i)The municipalities should have conducted preliminary work inherent to $\mathrm{CBC}$; (ii) the cooperation project must have shown consideration on the socio-cultural level; (iii) the distance among cities shall not be superior to $60 \mathrm{~km}$; (iv) the population of one of the cities at least should be no less than 20.000 inhabitants. Furthermore, previous researches were considered in order to identify which border cities meet the above-mentioned criteria.

The investigation was projected to locals, experts, and technicians related to the planning of the border cities. Thereby, a survey with two sections was

Figure 2. Chosen case studies (Authors).

(A) Haparanda - Tornio; (B) Valga - Valka; (C) Frankfurt Oder - Slubice; (D) Bayonne - San Sebastian; (E) Chaves - Verín; (F)

Tuy - Valença; (G) Cieszin - Cesky Tesín; (H) Gorizia - Nova Gorica; (I) Oradea - Debrecen

conducted informal interviews with stakeholders, experts, and main-actors of those borderlands to determine the critical challenges that must be conducted - section A, with a total of four questions - closed-up questions by an assessment method, and section $\mathrm{B}$, composed by multiple-choice questions.
- Haparanda-Tornio

- Valga-Valka

- Frankfurt Oder-Slubice

- Bayonne-San Sebastian

- Chaves-Verín

- Tuy-Valença

- Cieszin-Cesky Tesin

- Gorizia-Nova Gorica

- Oradea-Debrecen

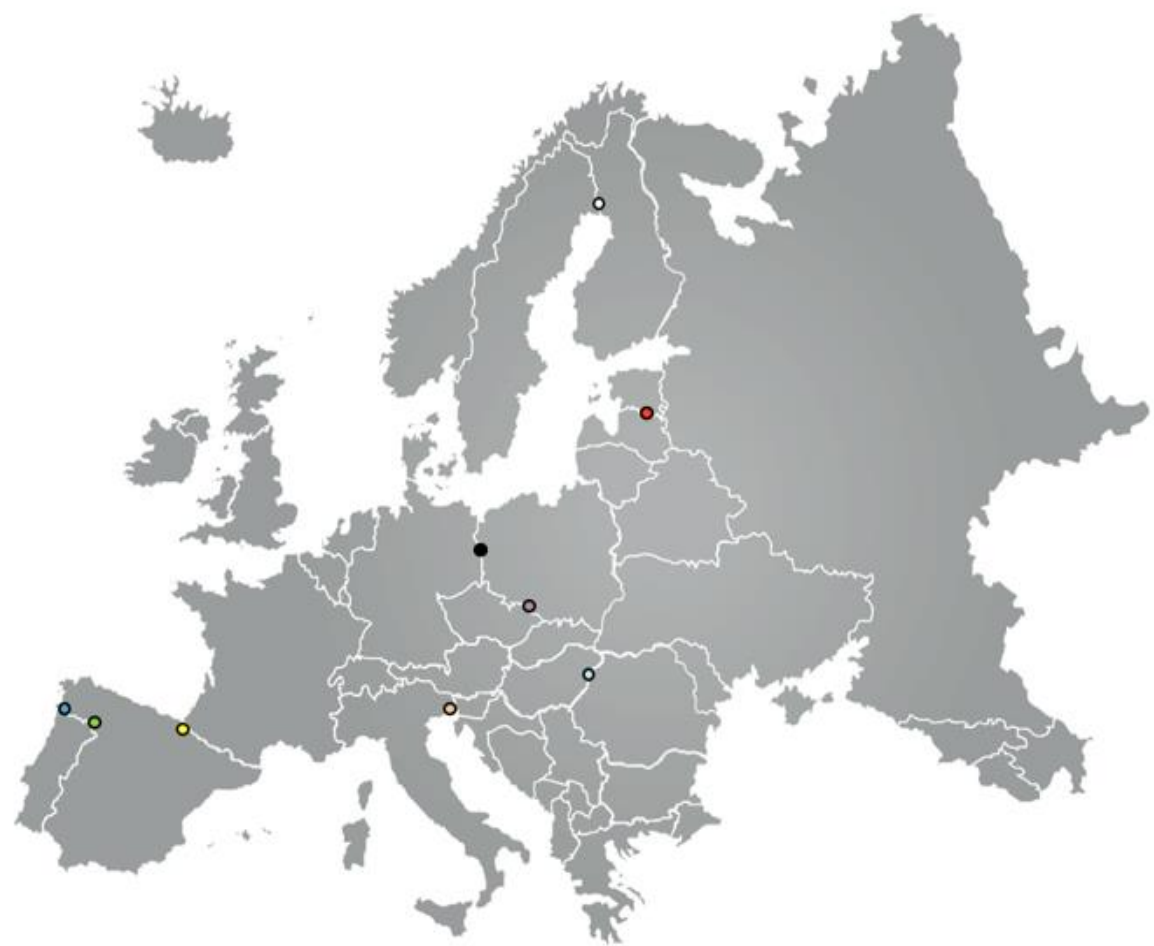

The questionnaires were conducted in the years 2016 and 2017. The sampling was composed of the actors answered across the current work. Furthermore, through the literature review became possible to 
In order to investigate the citizens' impressions,

\begin{tabular}{|c|c|c|c|c|c|c|c|}
\hline Case study & Population & $\begin{array}{c}\text { Distance } \\
\text { between } \\
\text { cities } \\
(\mathrm{Km})\end{array}$ & $\begin{array}{l}\text { Strategy of territorial } \\
\text { development }\end{array}$ & $\begin{array}{l}\text { Border } \\
\text { typology }\end{array}$ & $\begin{array}{l}\text { Pre-owned } \\
\text { dialects }\end{array}$ & Currency & $\begin{array}{l}\text { GDP/capita } \\
\text { (million } \\
\text { euros) }\end{array}$ \\
\hline Haparanda & 9500 & \multirow[b]{2}{*}{5} & \multirow[b]{2}{*}{ HaparandaTornio } & \multirow{2}{*}{$\begin{array}{l}\text { Schengen } \\
\text { Area }\end{array}$} & Swedish & \multirow[t]{2}{*}{ SEK } & 36000 \\
\hline Tornio & 22000 & & & & Finnish & & 24000 \\
\hline \multirow{2}{*}{$\begin{array}{l}\text { Valga } \\
\text { Tabte 1. Out } \\
\text { Valka }\end{array}$} & \multirow{2}{*}{ ine of the in } & \multirow{2}{*}{ direct anal } & \multirow{2}{*}{ ysismonationalelstu } & \multirow{2}{*}{ ly [1chengen } & $\begin{array}{l}\text { Estonian, } \\
\text { Russian }\end{array}$ & \multirow{2}{*}{ EUR } & 12000 \\
\hline & & & & & $\begin{array}{l}\text { Latvian, } \\
\text { Russian }\end{array}$ & & 10000 \\
\hline $\begin{array}{l}\text { Frankfurt } \\
\text { Oder }\end{array}$ & 60000 & \multirow{2}{*}{1} & \multirow{2}{*}{$\begin{array}{c}\text { Action Plan } \\
\text { Frankfurt-Slubice } \\
2010-2020\end{array}$} & \multirow{2}{*}{$\begin{array}{l}\text { Schengen } \\
\text { Area }\end{array}$} & German & EUR & 22000 \\
\hline Slubice & 20000 & & & & Polish & PLN & 13500 \\
\hline Bayonne & 44500 & \multirow[b]{2}{*}{45} & \multirow{2}{*}{$\begin{array}{c}\text { White Book \& } \\
\text { Strategic Plan 2014- } \\
2020\end{array}$} & \multirow[b]{2}{*}{$\begin{array}{c}\text { Schengen } \\
\text { Area }\end{array}$} & French & \multirow[b]{2}{*}{ EUR } & 33500 \\
\hline $\begin{array}{c}\text { San } \\
\text { Sebastian }\end{array}$ & 186500 & & & & Spanish & & 24000 \\
\hline Chaves & 41200 & \multirow{2}{*}{25} & \multirow{2}{*}{ Agenda 2008} & \multirow{2}{*}{$\begin{array}{l}\text { Schengen } \\
\text { Area }\end{array}$} & Portuguese & \multirow{2}{*}{ EUR } & 13200 \\
\hline Verin & 18000 & & & & Spanish & & 21800 \\
\hline Tuy & 17000 & \multirow{2}{*}{3} & \multirow{2}{*}{ INTERREG/POCTEP } & \multirow{2}{*}{$\begin{array}{l}\text { Schengen } \\
\text { Area }\end{array}$} & Spanish & \multirow{2}{*}{ EUR } & 21800 \\
\hline Valenca & 14100 & & & & Portuguese & & 13200 \\
\hline Cieszin & 36100 & \multirow{2}{*}{1} & \multirow{2}{*}{$\begin{array}{c}\text { Euroregion Cieszyn } \\
\text { Silesia }\end{array}$} & \multirow{2}{*}{$\begin{array}{l}\text { Schengen } \\
\text { Area }\end{array}$} & Polish & PLN & 16000 \\
\hline Cesky Tesin & 26100 & & & & Czech & $\mathrm{CZK}$ & 17800 \\
\hline Gorizia & 35300 & \multirow[b]{2}{*}{3} & \multirow[b]{2}{*}{ AETC } & \multirow{2}{*}{$\begin{array}{c}\text { Schengen } \\
\text { Area }\end{array}$} & Italian & \multirow[b]{2}{*}{ EUR } & 27500 \\
\hline Nova Grerica & 32000 & & & & Slovenian & & 19700 \\
\hline Oradea & 200000 & \multirow[b]{2}{*}{60} & \multirow{2}{*}{$\begin{array}{l}\text { Euroregion Hajdú- } \\
\text { Bihar-Bihor }\end{array}$} & \multirow{2}{*}{$\begin{array}{c}\text { Outside } \\
\text { Schengen } \\
\text { Area }\end{array}$} & Romanian & RON & 10100 \\
\hline Debrecen & 205500 & & & & Hungarian & HUF & 12500 \\
\hline
\end{tabular}

resulting data from the questionnaires was organized, and then statistically analyzed using the Statistical Package for Social Sciences (SPSS). In this regard, the author used descriptive statistics to assess the outcomes proceeding from the previous analysis. Also, a Principal component analysis (PCA) was used.

\section{Results}

All through the contextual investigation assessment, a few information was gathered, to get a solid comprehension of the most significant issues that conceivable could impact the accomplishment of the CBC ventures (Table I). Consequently, general settings were dissected as measurable information for the number of inhabitants in the urban areas; information for the separation between the urban communities of these outskirt urban communities; the continuous methodology of the regional turn of events; the border typology; the pre-owned dialects and monetary forms; and, the GDP per capita.

\footnotetext{
${ }^{1}$ (a)In the cooperation area of both cities, there is a duplication of equipment; (b) There is an increasing access to information/data from both cities by local citizens; (c) In the cooperation area of both cities, there is a high quality of data exchanging the services level; (d) Through
}

four closed-up questions, through an assessment method (Likert scale), were asked to the residents. The persons engaged were asked to address their agreement level with four sentences, where: 1disagree (totally); and, 5-agree (totally) (Table 2). In this way, most of the sentences (a, and d) the chose answer was 3 in 5 points agreement scale. As to sentence $b$, the higher values were shared among 2 , 4 , and 5 agreement levels in the scale - thus, this sentence shows a tendency for agree.

Table 2. Assessment ratings questions ${ }^{1}$.

\begin{tabular}{|l|l|l|l|l|l|}
\hline \multirow{2}{*}{ Sentences } & \multicolumn{5}{|c|}{ Agreement level } \\
\cline { 2 - 6 } & 1 & 2 & 3 & 4 & 5 \\
\hline a & 0.0 & 16.6 & $\mathbf{6 1 . 1}$ & 16.1 & 5.5 \\
\hline
\end{tabular}

the implementation of the $\mathrm{CBC}$ strategy the job opportunities for both cities has increased. 


\begin{tabular}{|l|l|l|l|l|l|}
\hline b & 0.0 & $\mathbf{2 7 . 7}$ & 16.6 & $\mathbf{2 7 . 7}$ & $\mathbf{2 7 . 7}$ \\
\hline c & 0.0 & $\mathbf{2 2 . 2}$ & $\mathbf{2 2 . 2}$ & $\mathbf{2 2 . 2}$ & $\mathbf{2 2 . 2}$ \\
\hline d & 0.0 & 5.5 & $\mathbf{3 8 . 8}$ & 27.7 & 22.2 \\
\hline
\end{tabular}

Sentence c, divided into equal choices between the agreement points 2, 3, 4, and 5, 22.2\% each. The sentence with a higher tendency to disagree was (b): "There is increasing access to information/data from both cities by local citizens?". On the opposite, the sentence with a higher tendency to agree was (d): "Through the implementation of the CBC strategy, the job opportunities for both cities have increased."

Moreover, different questions (questions X and $\mathrm{Y}$, Table 3) were utilized, where the members ought to highlight the three most relevant components for regional accomplishment in $\mathrm{CBC}$ ventures. Moreover, the members were additionally approached to reply to another question, where they ought to highlight the three principle challenges urban areas need to consider in CBC. The participants highlighted the reducing loss of young citizens as the major challenge for regional $\mathrm{CBC}$; and the sense of belonging and cultural barriers for the border cities' cooperation.

Table 3. Multiple-Choice questions (a and b) ${ }^{2}$.

\begin{tabular}{|c|c|c|}
\hline CBC Challenges & $\mathrm{X}$ & $\mathrm{Y}$ \\
\hline $\begin{array}{c}\text { (i) } \begin{array}{c}\text { Connectivity - movement } \\
\text { between cities }\end{array} \\
\text { (ii) Development of a strong } \\
\text { territorial strategy }\end{array}$ & 5.5 & 1.9 \\
\hline $\begin{array}{c}\text { (iii) Strategies for no equipment } \\
\text { duplication }\end{array}$ & 7.4 & 3.7 \\
\hline $\begin{array}{c}\text { (iv) Sense of belonging and } \\
\text { cultural barriers }\end{array}$ & $\mathbf{1 4 . 8}$ \\
\hline $\begin{array}{c}\text { (v) Euro Citizenship } \\
\text { (vi) Access European funds }\end{array}$ & 5.5 & $\mathbf{2 2 . 2}$ \\
\hline $\begin{array}{c}\text { (vii) Proximity to socioeconomic } \\
\text { flows }\end{array}$ & 3.7 & 0.0 \\
\hline $\begin{array}{c}\text { (viii) Local planning and life's } \\
\text { quality standards }\end{array}$ & $\mathbf{9 . 3}$ & 7.4 \\
\hline
\end{tabular}

${ }^{2}(\mathrm{X})$ Please highlight the three principle challenges for territorial success in $\mathrm{CBC}$ projects? (Y) Please highlight the three principle challenges cities should consider in $\mathrm{CBC}$ ?

\begin{tabular}{|c|c|c|}
\hline $\begin{array}{c}\text { (ix) Reducing the loss of young } \\
\text { citizens }\end{array}$ & $\mathbf{1 4 . 8}$ & 9.6 \\
\hline $\begin{array}{c}\text { (x) Common planning master } \\
\text { plans }\end{array}$ & 3.7 & $\mathbf{1 8 . 5}$ \\
\hline $\begin{array}{c}\text { (xi) Political engagement } \\
\text { (xii) Public participation }\end{array}$ & $\mathbf{9 . 3}$ & 9.6 \\
\hline $\begin{array}{c}\text { (xiii) Transparency and } \\
\text { engagement between cities }\end{array}$ & 5.5 & 3.7 \\
\hline $\begin{array}{c}\text { (xiv) Project marketing and } \\
\text { advertisement }\end{array}$ & 5.5 & 0.0 \\
\hline
\end{tabular}

Also, advanced statistics were used - PCA. By that analysis, fourteen variables were investigated (Table 4). The variables (iv), and (ix) are the ones that could be considered the principals' variables. In the first place, we have the variable (iv), followed by (ix).

Table 4. Analyzed variables/components.

\begin{tabular}{|l|l|}
\hline Analyzed variables/components & $\begin{array}{l}\% \\
\text { variance }\end{array}$ \\
\hline $\begin{array}{l}\text { (i) Connectivity - movement between cities } \\
\text { (ii) Development of a strong territorial }\end{array}$ & -.81 \\
\hline strategy & -.92 \\
\hline $\begin{array}{l}\text { (iii) Strategies for no equipment duplication } \\
\text { (iv) Sense of belonging and cultural barriers }\end{array}$ & .73 \\
\hline $\begin{array}{l}\text { (v) Euro Citizenship } \\
\text { (vi) Access European funds }\end{array}$ \\
\hline \begin{tabular}{l} 
(vii) Proximity to socioeconomic flows \\
\hline (viii) Local planning and life's quality \\
standards
\end{tabular} & -1.32 \\
\hline \begin{tabular}{l} 
(ix) Reducing the loss of young citizens \\
\hline (x) Common planning master plans
\end{tabular} & $\mathbf{1 . 4 2}$ \\
\hline (xi) Political engagement & .49 \\
\hline (xii) Public participation & .53 \\
\hline
\end{tabular}




\begin{tabular}{|l|l|}
\hline $\begin{array}{l}\text { (xiii) Transparency and engagement between } \\
\text { cities }\end{array}$ & -.46 \\
\hline \begin{tabular}{l} 
(xiv) Project marketing and advertisement \\
\hline
\end{tabular} & -.81 \\
\hline
\end{tabular}

Besides, from the study of Castanho et al. [27], where fourteen critical factors for CBC projects have been identified, we have studied them to isolate the ones that connect the socio-cultural theme solely. Thus, five specific critical factors were isolated (Tables 5 and 6).

Table 5. Socio-Cultural crucial factors.

\begin{tabular}{|l|l|}
\hline P1 & Sense of belonging and break cultural barriers \\
\hline P2 & Diverse infrastructural offer - Euro Citizenship \\
\hline P3 & Better life's quality standards \\
\hline P4 & Retain young and talented people \\
\hline P5 & Public participation \\
\hline
\end{tabular}

Table 6. Socio-Cultural crucial factors connected with the case study.

\begin{tabular}{|l|c|c|c|l|l|}
\hline Case studies & P1 & P2 & P3 & P4 & P5 \\
\hline Haparanda-Tornio & X & & & & \\
\hline Valga-Valka & X & & X & & \\
\hline Frankfurt Oder-Slubice & X & & & X & \\
\hline Bayonne-San Sebastian & X & & & & X \\
\hline Chaves-Verín & & X & & & \\
\hline Tuy - Valença & & X & & X & \\
\hline Cieszin-Cesky Tesín & & & $\mathbf{X}$ & & \\
\hline Gorizia-Nova Gorica & & & $\mathbf{X}$ & & \\
\hline Oradea-Debrecen & & & $\mathbf{X}$ & & \\
\hline
\end{tabular}

\section{Discussion}

Through the examination of Table 1 , it is conceivable to quickly comprehend the primary highlights of the border cities inside the CBC condition From this table, significant contrasts should be highlighted as the demographic dynamics between the cities of Haparanda and Tornio, Frankfurt Oder and Slubice, Valga and Valka, Bayonne and San Sebastian (the city of San Sebastian has four times more population than Bayonne), or even, the Portuguese city of Chaves and the Spanish city of Verín. Concerning the distance between cities, we have Oradea and Debrecen with the maximum distance possible of the pre-selection criteria $(60 \mathrm{~km})$, the border cities of Frankfurt Oder and Slubice, and Cieszyn and Cesky Tesin with a distance around $1 \mathrm{Km}$ separating their urban centers. Nevertheless, as other similar studies have already shown, the distance has no much significance in the success of the CBC $[27,28,29]$. In this regard, we have the example of the border cities of La Línea de la Concepción (Spain) and Gibraltar (Gibraltar-UK), where the $\mathrm{CBC}$ is seen as a failure [10]. The cities of Oradea and Debrecen have a No Schengen Area Typology; this is another exciting outcome we can retain from this table. It is well known all the benefits that the Schengen agreement may provide to the $\mathrm{CBC}[30,31]$, however, in this particular case, the cities show exceptional indicators, which could raise some questions regarding some of the EU policies and approaches towards the $\mathrm{CBC}$ ventures. Regarding the GDP/per capita indicator, it is possible to denote some unbalances. For example, in the cities of ChavesVerín and Tuy-Valença (favoring the Spanish cities), or Bayonne-San Sebástian (with a higher GDP in the French side of the border), or Frankfurt Oder-Slubice (with the GDP favoring the German city).

By the examination of Table 2, where the participants were approached to address the understanding level with four sentences, it is conceivable to confirm that two of the sentences show an exact position (sentences a, and d). Sentences $\mathrm{b}$ and $\mathrm{c}$ divided the participants' opinions; nevertheless, both have shown a tendency to the agreement (being in sentence $b$, this tendency more evident). Concerning the affirmation a (In the cooperation area of both cities, there is a duplication of equipment), the participants showed an inconclusive opinion with $61.1 \%$ of the answers concentrated in the middle of the agreement scale; however, a small positive tendency was identified. Focusing on sentence $b$ (There is increasing access to information/data from both cities by local citizens), the opinions were divided equally, with $27.7 \%$ of the agreement in points 2, 4, and 5 of the Likert Scale - 
showing a tendency to the agreement. With the affirmation In the cooperation area of both cities, there is a high quality of data exchanging the services level (sentence c), the participants' opinions divided once again, and equally shared among the agreement in points 2, 3, 4, and 5 of the Likert Scale (with $22.2 \%$ each). Contextually, sentence $d$ (Through the implementation of the CBC strategy, the job opportunities for both cities have increased), the answers showed an exact position of unclearness once the highest percentage was found in the agreement point 3 (with 38.8); even though, this affirmation also shows a slight agreement tendency. However, if we consider that the decision-makers and $\mathrm{CBC}$ representatives promise and announce better life quality standards, and many job opportunities for the local populations with the implementation of such border strategies - i.e., a recurrent situation in many of the Iberian Eurocities projects [28]; therefore, it was expected that those border populations select a higher level of agreement with this affirmation; which is are unfavorable findings for the government officials associated with this typology of activities. Indeed, past investigations confirm these discoveries and perspectives - i.e., $[18,19,23,32,33,34,35,36$, $37,38,39]$ are just some examples.

Through the analysis of tables 3 and 4 , it is possible to isolate the most relevant challenges that the border actors consider essential for the success of a regional and local CBC venture from a sociocultural perspective. For the success on a regional scale, the most relevant challenges were: reducing the loss of young citizens (14.8\%), public participation (14.8), and the sense of belonging and cultural barriers. If we consider the success on a local scale (city-to-city cooperation): the sense of belonging and cultural barriers (22.2); common planning master plans (18.5), and strategies for no equipment duplication (14.8). Besides, throughout the application of a (PCA) to the previously selected challenges, it was possible to isolate two: the sense of belonging and cultural barriers; and the reducing the loss of young citizens. Also, table 6 corroborates, in part, these findings, once the factors P1 (sense of belonging and cultural barriers), the most identified factor in the case studies. However, P3 (better life quality standards) were also identified in many case studies as P1 - revealing that some factors could have a higher weight than others in different borderlands realities. Therefore, and considering the existing multidisciplinary literature [see: $11,40,41,42,43$, $44,45,46]$ we obtain five critical factors for CBC territorial success, from a socio-cultural perspective.

Considering the outcomes mentioned above, we should further analyze and crossing them with the actual panorama ongoing in EU -i.e., the pandemic crisis of COVID-19 (pandemic crisis); Brexit; the refugees' fluxes; increase of nationalism; among many others significant obstacles that may jeopardize the CBC success. Here, it should be highlighted the recent pandemic crisis of COVID-19 and the possible last-longing impacts over the CBC. For example, the cut of freedom of movement within EU territories or the rise of nationalism fractions (dangerously increasing the sense of belonging and the cultural barriers). Such issues are already affecting international relationships worldwide and, consequently, the common strategic planning - i.e., the case of some countries in the Balkans regions, among many other examples. Also, there is the Brexit, which is now an obstacle to many ongoing $\mathrm{CBC}$ projects and several others even before they came out of the paper. Based on the exposed, we can observe that $\mathrm{CBC}$ is and the common strategic planning associated, are processes that require constant monitoring and assessment to achieve the so-desired sustainability.

\section{Conclusion}

With this study, we were able to define not only the most relevant challenges to consider in CBC ventures as well as to identify the essential factors for the success of these border projects from a socio-cultural perspective. Thus, the most relevant challenges to consider are:

- reducing the loss of young citizens

- public participation

- sense of belonging and break cultural barriers

- common planning master plans

- strategies for no equipment duplication

Also, the critical factors to consider in CBC, from a socio-cultural perspective are:

- sense of belonging and break cultural barriers

- diverse infrastructural offer - Euro Citizenship

- better life's quality standards

- retain young and talented people

- public participation

Also, and dependent on the various highlights and singularities of the analyzed cities, it appears the factors don't have a similar relevance over every European CBC Project.

Contextually, if we consider the direct and indirect results, it is possible to extract guidelines for 
proper design, implementation, and management of the common strategic planning directed to the CBC projects, considering the socio-cultural sphere. Thereby, the proposed principles are:

- creation of strategies to improve the rural and urban life quality standards $[12,19,47,48]$;

- a more robust political engagement and transparency $[18,49]$;

- promote stakeholders' active involvement public participation $[50,51,52]$;

- invert on an economic system that meets the needs of its citizens [53,54];

- promote employment that can rejuvenate its population [54], and at the same time increase the regional and local know-how $[12,55]$;

- no social discrimination and opportunities equality [56];

- conservation and preservation of the border ecological systems - promote interactions between societies and the environment [57, 58];

- foster synergies that sustain areas with ecological and cultural heritage values [59].

Moreover, the main-actors and decision-makers responsible for these border territories should focus on the creation of coherent pubic policies that focus on sustainable development, enabling significant investments regarding infrastructure and services $[22,60,61,62]$. Therefore, and considering the horizontal scope of sustainable development and consequently, for the common strategic planning, it is pivotal to exist narrow cooperation among the public sector, the private sector, communities, and civil society $[19,63,64]$.

Indeed, previous studies were already focused on the investigation over the influential factors for the success in borderlands (see: $[11,18,19,27,61,65$, 66, 67]; among many other pieces of research); however, such factors have never been isolated from a socio-cultural perspective. For a full understanding of the border territories, future studies should be carried out in other EU cities, regions, and environments.

Also, more case studies should be analyzed, and more questionnaires implemented to keep the data updated. Therefore, it will allow us to understand this issue in more detail.

\section{References:}

[1] Duh S, Stead D, Zonneveld W. (2007), The Europeanization of spatial planning through territorial cooperation. Planning, Practice \&
Research. 22(3):291-307. 2007 DOI: 10.1080/ 02697450701688245

[2] Nauwelaers, C., K. Maguire and G. Ajmone Marsan. The Case of Helsinki-Tallinn (FinlandEstonia) - Regions and Innovation: Collaborating Across Borders. OECD Regional Development Working Papers, 2013/19, OECD Publishing. 2013. http://dx.doi.org/10.1787/5k3xv01rt1r6-en

[3] Bacova A, Puskar B, Vrablova E. New Housing Models-Case Studies. Albena, Bulgaria: SGEM; 2015. DOI: 10.5593/ sgem2015/b62/s27.066. Pub. SGEM. Albena, Bulgaria

[4] Sohn, C. and Giffinger, R. A Policy Network Approach to Cross-Border Metropolitan Governance: The Cases of Vienna and Bratislava. Eur. Plan. Stud. J. 23, 1187-1208. 2015

[5] Task Force on the United States-Mexico Border. Managing the United States- Mexico Border: Cooperative solutions to common challenges. Full Report of the Binational Task Force on the United States-Mexico Border. 2009

[6] Lee, S., \& Na, S. E-Waste recycling systems and sound circulative economies in East Asia: A comparative analysis of systems in Japan, South Korea, China and Taiwan. Sustainability Journal, 1632-1644. 2010

[7] Medhekar, A., and Haq, F. Cross-Border Cooperation for Bilateral Trade, Travel, and Tourism: A Challenge for India and Pakistan. Cross-Border Cooperation (CBC) Strategies for Sustainable Development. IGI Global. 1 - 1, pp.168 - 191. 2020

[8] Tasbasi, A., Sarıca, P, and Yü sel, A. Scale Matters: Cross-Scale Dynamics of CrossBorder Carbon Adjustments. Cross-Border Cooperation (CBC) Strategies for Sustainable Development. IGI Global. 1 - 1, pp.86 - 100. 2020

[9] Domínguez, J. A., Noronha Vaz, T., \& Vaz, E. Sustainability in the trans-border regions? The case of Adalusia e Algarve. International Journal of Global Environmental Issues, 14(1/2), 151e163. 2015

[10] Castanho, R., (2017). Sustainable Urban Planning in transboundary areas: analysis of critical factors for territorial success. Ph.D. Thesis, University of Extremadura (UEx), Badajoz, Spain, 2017.

[11] Loures, L., Castanho, R.A., Naranjo Gómez, J., Lousada, S., Fernández-Pozo, L., Cabezas, J., and Loures, A. Impactos Socioculturais da Cooperação $\mathrm{T}$ ransfronteiriça $(\mathrm{CT})$ no Espaço 
Europeu. Fronteiras: Journal of Social, Technological and Environmental Science p292-312. ISSN 2238- 8869. 2019.

[12] Loures, L.; Castanho, R.; Naranjo, J.; Cabezas, J.; Fernández- Pozo, L. The influence of crossborder cooperation $(C B C)$ in the fostering of entrepreneurship and regional development-a step closer to achieve major structural changes and sustainable cities within European Territory. Series: Entrepreneurship and Structural Change in Dynamic Territories. In New Paths of Entrepreneurship Development; Carvalho, L., Rego, C., Lucas, M., Hérnandez, I., Viana, A., Eds.; Ed. Springer: Canada, pp. 371-385. 2019.

[13] Vulevic, A., Castanho, R.A., Naranjo Gómez, J.M., Loures, L., Cabezas, J., Fernández-Pozo, L., and Martín Gallardo, J. Accessibility Dynamics and Regional Cross-Border Cooperation (CBC) Perspectives in the Portuguese-Spanish Borderland. Sustainability 12. 2020

[14] Mora Aliseda J., Mora C., Garrido Velarde J. Demographic structures and the geographical distribution of the municipalities of the Guadiana hydrographic basin: Iberian Peninsula. Wseas transactions on environment and development, Vol 14, 2018.

[15] Mora Aliseda J., Garrido Velarde J., Bedón Garzó R. Indicators for sustainable management in the Yasuni national park. Wseas transactions on business and economics, Vol 14, 2017

[16] Baptista T, Caballero C, Ceballos F, Carriço C, Mateus J, and Lopes H. IDE-OTALEXC. The first crossborder SDI between Portugal and Spain: Background and development. Journal of Earth Science and Engineering. 2013

[17] Trillo Santamaria, J., González, R., \& Paü, V. Border-crossing cities: A critical analysis on the eurocidade chaves-verin project. Geographic Journal, 54(1), 160-185. 2015

[18] Castanho, R.A. Identifying Processes of Smart Planning, Governance and Management in European Border Cities. Learning from Cityto- City Cooperation (C2C). Sustainability, 11. 2019

[19] Loures, L., Castanho, R.A., Vulevic, A., Naranjo Gómez, J., Cabezas, J. and FernándezPozo, L. The Multi-variated Effect of City Cooperation in Land Use Planning and Decision-making Processes - a European Analysis. Chapter in the Book: Urban Agglomerations. Ed. InTech. ISBN 978-953-515884-4 pp.87-106. 2018.
[20] Medeiros E. (2015), Territorial impact assessment and cross-border cooperation. Regional Studies, Regional Science. 2(1):97115. 2015

[21] Vulevic, A. Accessibility Concepts and Indicators in Transportation Strategic Planning Issues: Theoretical Framework and Literature Review. Logistics \& Sustainable Transport, vol. 7, no. 1, pp. 58-67. 2016

[22] Naranjo, J. M. Impacts on the social cohesion of mainland Spain's future motorway and highspeed rail networks. Sustainability, 8(7), 624. 2016

[23] Batista, T., Ceballos-Zúñiga, F., Carriço, C., Pinto-Gomes, C., Fernández-Pozo, L., Naranjo Gómez, J., Martín-Gallardo, J, Loures, L., Cabezas, J. Benefits of a Spatial Data Infrastructure on the Sustainability of a Southwestern European Territory. CrossBorder Cooperation (CBC) Strategies for Sustainable Development. 1 - IGI Global. 1, pp. $1-29.2020$.

[24] Mora Aliseda J., Garrido Velarde J., Díaz González M. Population analysis of the SpanishPortuguese basin of the river Tajo. Wseas transactions on environment and development, Vol 13, 2017.

[25] Yin, R. Case study research: Design and methods. London: Sage Publications. 1994

[26] Eurostat. Eurostat - Statistics Explained. Accessed on October 3, 2017. available at: www.ec.europa.es.

[27] Castanho, R. A., Vulevic, A., Cabezas, J., Fernández-Pozo, L. Goméz-Naranjo, J. \& Loures, L. Accessibility and connectivity Movement between cities, as a critical factor to achieve success on cross-border cooperation (CBC) projects. A European analysis. Sustainable Cities and Society. Vol 32,181-190. 2017.

[28] Vulevic, A., Castanho, R.A., Gómez-Naranjo, J., Cabezas, J. and Fernández-Pozo, L. (2017). Transport Accessibility to Achieve Sustainable Development. Principles for its Application in CBC Projects: The Euro-City Elvas-Badajoz. Proceedings Book - 16th Congress on Public and Nonprofit Marketing (IAPNM). Conference Proceedings First Ed. 2017. Badajoz. ISBN: 978-84-697-5643-0.

[29] Gamon, W., and Gómez, J. Main Problems of Railway Cross-Border Transport Between Poland, Germany and Czech Republic. Sustainability. 11. 2019

[30] Veemaa, J. Internationalizing the Spatial Identity of Cross-Border Cooperation. 
European Planning Studies Vol, 20 (10): 16471666. 2012

[31] Martín, G. Border Space as a Vehicle for Territorial Cooperation in the New Programming Period 2014-2020, OTALEX-C. Direccíon General de Transportes, Ordenación del Territorio e Urbanismo, Consejeria de Fomento, Vivienda, Ordenación del Territorio y Turismo; Junta de Extyremadura: Badajoz, Spain, 2013.

[32] Hooghe, L. and Marks, G. Contrasting Visions of Multi-Level Governance. Bache, I. and Flinders, M. (eds.) Multi-Level Governance, Oxford: Oxford University Press, pp. 15-30. 2004.

[33] Spirkova, D., and Ivanicka, K. Dynamics of Bratislava urban and housing development. New models for innovative management and urban dynamics. University of Algarve: Faro, Portugal. 2009.

[34] Dominguez, L. and Pires, I. (2014). Crossborder cooperation structures in Europe. Learning from the past, looking to the future. Brussels: P.I.E. Peter Lang. 2014.

[35] Faludi, A. (2013). Territorial Cohesion and Subsidiarity under the European Union Treaties: A Critique of the «Territorialism» Underlying. Regional studies. Vol. 47 (9) pp. 1594-1606.

[36] Rabé P, Toto R, and Dhima S. Analyzing the Likely Impact of European Union Policies on Territorial Planning in Albania. Rotterdam, Netherlands: Netherlands government (MATRA). 2013.

[37] Fadigas, L. Território e Poder. O uso, as políticas e o ordenamento. Ed. Sílabo: Lisboa, Portugal, 2017.

[38] Gualini, E. Political economy of scale in European spatial policy. In: Rethinking European Spatial Policy as a Hologram: Actions, Institutions, Discourses. London, United Kingdom: Routledge; 2017

[39] Vulevic, A., Castanho, R.A., Naranjo Gómez, J.M., Loures, L., Cabezas, J., Fernández-Pozo, L., and Martín Gallardo, J. Accessibility Dynamics and Regional Cross-Border Cooperation (CBC) Perspectives in the Portuguese-Spanish Borderland. Sustainability. 12, 2020.

[40] Buis $H$. The role of local government associations in increasing the effectiveness of city-to-city cooperation. Habitat International. 2009;33(2):190-194. 2008.

[41] Stead D, Waterhout B. Learning from the application of the ESDP: Influences on
European Territorial Governance. disP: The Planning Review. 44(172):21-34. 2008.

[42] Nicolini, E., and Pinto, M. Strategic vision of a Euro-Mediterranean port city: A case study of palermo. Sustainability Journal. (5), 3941-3959. 2013

[43] Reitel, B. Are Cross-Border Urban Spaces European Integration Patterns at Local Level? Analysis of the Management of Urban Areas astride the "French Border». Borders of the European Union: Strategies of Crossing and Resistance. 2015.

[44] Decoville, A., and Durand F. Challenges and Obstacles in the Production of Cross-Border Territorial Strategies: The Example of the Greater Region. Transactions of the Associations of the European Schools of Planning Journal. Vol.1, (1), pp. 65-78. 2017.

[45] Suchacek, J.; Stverkova, H.; Kasik, J. Czech Machinery Cluster and Its Role in Sustainable Development of Moravian-Silesian Enterprises during the Post-Transformation Era. Sustainability. 10. 2018.

[46] Huisseling D., and Mora Aliseda, J. Los Movimientos Soberanistas Como Amenaza a la Integridad Territorial de los Estados y de la UE. Revista Extremeña de Sociología Almenara. 11, 59-72. 2019.

[47] Garrido Velarde J., Montero Parejo M.J., Hernández-Blanco J., García Moruno L. Using Native Vegetation Screens to Lessen the Visual Impact of Rural Buildings in the Sierras de Béjar and Francia Biosphere Reserve: Case Studies and Public Survey. Sustainability, 11, 2019

[48] Garrido Velarde J., Montero Parejo M.J., Hernández Blanco J., García Moruno L. Visual analysis of the height ratio between building and background vegetation. Two rural cases of study: Spain and Sweden. Sustainability, 10, 2018

[49] González- Gómez, T., and Gualda, E. Reporting a bottom- up political process: Local perceptions of cross- border cooperation in the southern Portugal-Spain region. European Urban and Regional Studies. 23(3), 468-480. 2016.

[50] Loures L, and Crawford P. Democracy in progress: using public participation in postindustrial landscape (re)-development. WSEAS Transactions on Environment and Development, Vol. 4(9) 794-803. 2008.

[51] Loures, L., Naranjo Gómez, J.M., Castanho, R.A., and Loures, A. Benefits and Limitations of Public Involvement Processes in Landscape 
Redevelopment Projects-Learning from Practice. Chapter in the Book: Regional Intelligence Spatial Analysis and Anthropogenic Regional Challenges in the Digital Age. Ed. Springer. pp. 29-48. 2020.

[52] Garrido Velarde J., Montero Parejo M.J., Hernández Blanco J., García Moruno L. Use of video and $3 \mathrm{D}$ scenario visualisation to rate vegetation screens for integrating buildings into the landscape. Sustainability, 9, 2017

[53] Spangenberg, J., (1995). Towards Sustainable Europe, A Study from the Wuppertal Institute for Friends of the Earth Europe. Luton, UK. 1995

[54] Spangenberg, J. Economic sustainability of the economy: Concepts and indicators. International Journal of Sustainable Development. 8. 2005.

[55] Ferreira, P., Loures, L., and Serafim, M. The Impact of Being a Border Region in Business Demography:

An.Analysis. in.the.European.Union. Cross-Border Cooperation (CBC) Strategies for Sustainable Development. IGI Global. 1 - 1, pp. 30 - 42. 2020.

[56] Miller, D. Border Regimes and Human Rights. CSSJ Working Papers Series, SJ021. Centre for the Study of Social Justice Department of Politics and International Relations University of Oxford. 2012.

[57] Yigitcanlar, T., Dur, F., Dizdarogluc, D. Towards prosperous sustainable cities: A multiscalar urban sustainability assessment approach, Habitat International: a journal for the study of human settlements. p36-46. 2015.

[58] Raposo, M., Castanho, R., Meireles, C., Santos, P. and Pinto-Gomes, C. (2018). Border Effect on Flora and Raptors Diversity. An Iberian Case. Chapter in the Book: Ordenación del espacio: Ciudades inteligentes, turismo y logística. Ed. Thomson Reuteurs Aranzadi. pp. 293-303. 2018.

[59] Fadahunsi, J.T. Application of Geographical Information System (GIS) Technology to Tourism Management in Ile- Ife, Osun State, Nigeria. Pac. J. Sci. Technol. 12, 274-283. 2011.

[60] Gudmundsson, H.; Mattias, H. Sustainable Development Principles and Their Implications for Transport. Ecol. Econ. 19, 269-282. 1996.

[61] Vulevic, A. Demographic response to accessibility improvement in depopulation cross border regions: The Case of Euro region Danube 21 in Serbia. In Proceeding Book, Faculty of Geography; University of Belgrade: Belgrade, Serbia, 2017;
[62] Naranjo Gómez, J., Castanho, R.A., Cabezas, J., Loures, L. Assessment of High-Speed Rail Service Coverage in Municipalities of Peninsular Spain. Infrastructures, 5, 11. 2020

[63] Pérez- Nieto, E. G. Centralization as a barrier to cross- border cooperation? Some preliminary notes from an Iberian approach. Journal of Borderlands Studies, 31(4), 481-495. 2016

[64] Liberato, D., Alén, E., Liberato, P., \& Domínguez, T. Governance and cooperation in Euroregions: Border tourism between Spain and Portugal. European Planning Studies, 26(7), 1347-1365. 2018.

[65] Magoulios, G., Sotirios, D., \& Kydros, D. Inter-border cooperation in the area of Serres Prefecture and consequences of the EU Bulgaria accession - an empirical research. In Procedia economics and finance book of the 5 th international con- ference on the economies of Balkan and Eastern Europe countries in the changed world (EBEEC). Istanbul, Turkey. ISSN: 2212- 5671. 2013

[66] Emontspool, J., \& Servais, P. Cross- border entrepreneurship in a global world: a critical reconceptuasilation. European Journal of International Management, 11(3), 262-279. 2017.

[67] Castanho, R. A., Vulevic, A., Cabezas, J., Fernández-Pozo, L. Goméz-Naranjo, J. \& Loures, L. Accessibility and connectivity Movement between cities, as a critical factor to achieve success on cross-border cooperation (CBC) projects. A European analysis. Sustainable Cities and Society - Vol. 32, 181190. 2017

\section{Sources of funding for research presented in a scientific article or scientific article itself}

The author would like to thank to the program of the Minister of Science and Higher Education titled "Regional Initiative of Excellence" in 2019-2022, project number $018 / \mathrm{RID} / 2018 / 19$, the amount of funding PLN 10788 423,16.

The authors wish to acknowledge funding for this research work from the VI Regional Research Plan and the Regional Government of Extremadura and the European Regional Development Fund (ERDF), associated with financing the research group Sustainable Development and Territorial Planning 
(GR18052) and the Environmental Resources Analysis Research Group (GR18054).

This work was supported by national funds through the Fundação para a Ciência e a Tecnologia, I.P. (Portuguese Foundation for Science and Technology) by the project UIDB/05064/2020 (VALORIZA Research Centre for Endogenous Resource Valorization).

\section{Creative Commons Attribution License 4.0} (Attribution 4.0 International, CC BY 4.0)

This article is published under the terms of the Creative Commons Attribution License 4.0

https://creativecommons.org/licenses/by/4.0/deed.en_US 